\title{
Effect of Ginger Warm Compresses on Pain Intensity Reduction in Patients with Rheumatoid Arthritis
}

\author{
Hamdana ${ }^{1,}$ Edison Siringoringo ${ }^{*}$, Eka Rahayu Nensi ${ }^{3}$ \\ Departemen Surgical and Medical Nursing, Stikes Panrita Husada Bulukumba, Indonesia ${ }^{1}$ \\ Departemen Surgical and Medical Nursing , Stikes Panrita Husada Bulukumba ,Indonesia ${ }^{2}$ \\ S1 Nursing Study Program, Stikes Panrita Husada Bulukumba, Indonesia ${ }^{3}$
}

\section{Corresponding Autor : edisonsiringoringo@gmail.com*}

\begin{abstract}
Rheumatoid arthritis is a musculoskeletal disease that affects many people, this disease causes many complaints including, pain in the legs, knees and various other joints. One of the nonpharmacological measures that can be done to reduce the intensity of pain is warm ginger compresses. Ginger contains essential oils with active ingredients school, gingerol, paradol and zingerone which are warm and can promote blood circulation. This study aims to determine the effect of ginger warm compresses on the reduction in pain intensity in patients with rheumatoid arthritis. This type of research is a pre-experiment with one group design pre-post test design. This research was conducted in May-2017. The samples in this study were 15 people who suffered from rheumatoid arthritis pain with consecutive sampling data collection techniques.

The results showed the intensity of rheumatoid arthritis pain before the warm ginger compress (pre-test) was average with moderate pain intensity. While the intensity of pain after a warm ginger compress (post-test) is average with mild pain intensity. Based on Wilcoxon's alternative paired t-test, p-value 0,000 $(<0.05)$ means that there is a significant influence between the effect of warm ginger compresses on the decrease in pain intensity in patients with rheumatoid arthritis. It is hoped to further develop several variables and add a long time to the administration of warm ginger compresses in rheumatoid arthritis so that the results of research on ginger warm compresses to reduce pain intensity in patients with rheumatoid arthritis are more optimal and can provide more accurate research results.
\end{abstract}

Keywords: Pain Intensity, Ginger Warm Compress, Rheumatoid Arthritis

\section{INTRODUCTION}

Disturbances in the joints are diseases that are often found in the community, and including diseases that are very closely related to the aging process. Diseases in the joints also become diseases that can cause death if not handled properly. One such disorder is Rheumatoid Arthritis. Pain has always been a major complaint in Rheumatoid Arthritis. Pain management in Rheumatoid Arthritis aims to reduce or eliminate pain and discomfort. Actions that can be taken by nurses are divided into two, namely pharmacological actions and nonpharmacological actions. One nonpharmacological action that can be done is to use warm compresses. according to 


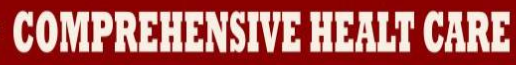

Cici Chintyawati (2014) in a research study conducted, showed the relationship of warm water compresses in the management of pain in patients with Rheumatoid Arthritis is very beneficial in reducing the pain suffered by patients.

One way to warm the joints is by using a warm ginger compress (Anggraeni, 2014). Ginger contains essential oil components with active substances shogunal, gingerol, paradol, and zingerone which are warm and can promote blood circulation (Hamid, 2013). Ginger is also very easy to find in any region because it is a drug that is trusted by the public to cure several diseases, according to Samsuddin et al (2016), the results of research studies conducted show a significant effect on the administration of warm compresses using grated red ginger (zingiber officinale roscoe var rub run ) against decreasing gout arthritis pain. World Health Organization (WHO) estimates that there are around 305 million people with Rheumatoid Arthritis, meaning that 1 in 6 people on earth suffer from Rheumatoid Arthritis. In Indonesia, the prevalence of Rheumatoid Arthritis pain is $11.9 \%$ based on the diagnosis of health and $24.7 \%$ based on diagnosis or symptoms. Based on Indonesia's health profile in 2013, Rheumatoid Arthritis cases ranks fifth from the data of 11 main illnesses in hospital patients with a percentage of 3.15\%. RISKESDAS data (2013) shows the prevalence of Rheumatoid Arthritis in South Sulawesi is $27.7 \%$ and the Health Office of Bulukumba in 2013 totaling 3200 people and those suffering from Rheumatoid Arthritis in 2014 were 5230 people, and in 2015 were 5830 people. Data obtained from the Bontobahari Public Health Center showed that in 2015 there were 335 people, while there was an increase in 2016 where the number of patients with Rheumatoid Arthritis was 1,070 people.

Based on the results of a survey conducted by researchers in the work area of the Bontobahari puskesmas on January 23, 2017, sufferers of Rheumatoid Arthritis complain of pain and have daily activities of gardening by growing vegetables such as beans and consumed daily which can aggravate the disease of Rheumatoid Arthritis. Then the researchers interviewed 5 patients, the researchers asked the actions taken by patients to relieve pain. Patients answered 1 person massaging the sick body part with balm and 1 person without balm, 2 there were taking medication and 1 who was compressing warm. Based on the results of previous surveys of Rheumatoid Arthritis sufferers in the work area of the Bontobahari Puskesmas, there are still very few who use warm compresses to reduce pain and unhealthy eating patterns where the patient still consumes food that can increase Rheumatoid Arthritis disease. To be able to raise 


\section{COMPRABHENSWE HEAH CARE}

this intervention to the surface, it is necessary to prove the effectiveness of this action in reducing the intensity of pain in patients with Rheumatoid Arthritis.

The impact is that people who suffer from Rheumatoid Arthritis will increase and if Rheumatoid Arthritis pain is not treated quickly and correctly it will cause paralysis, disruption of activity, and even cause death. For this reason, researchers are interested in researching the effect of ginger warm compresses on reducing the intensity of Rheumatoid Arthritis pain in the work area of the Bontobahari puskesmas.

\section{MATERIAL AND METHODS}

In this study, before a warm ginger compress (pre-test) was performed, the scale of Rheumatoid Arthritis pain was measured. Then the researchers did a warm compress of ginger for 20 minutes with 1-time administration, after that, it was measured again (post-test) the pain scale of the patient. Then compared between pre-test pain and posttest. Population is an object or subject that is in an area and meets certain requirements with research problems (Dr. Syamsuddin et al, 2015: 126).

The population in this study were all patients with Rheumatoid Arthritis in the work area of the Bontobahari Puskesmas, with a total of 1,070 Rheumatoid Arthritis sufferers. It is part of the population to be studied or part of the number of characteristics possessed by the population used for research (Sujarweni, 2014). Researchers using sampling techniques with consecutive sampling is a selection of samples by specifying subjects that meet the research criteria included in the study until a certain period so that the required number of samples is met (Sujarweni, 2014). The number of samples in this study were 15 people who suffered from Rheumatoid Arthritis pain. Analysis carried out more than two variables that serve to determine the relationship between variables. The analysis used in bivariate analysis with an alternative paired Wilcoxon ttest using the SPSS application.

\section{RESULTS}

Table 1 Distribution of Respondent Frequencies by Age and Gender

\begin{tabular}{lcc}
\hline Age & n & Percentage (\%) \\
\hline $45-49$ & 2 & $14 \%$ \\
$50-54$ & 5 & $33 \%$ \\
$55-60$ & 8 & $53 \%$ \\
Gender & & \\
Female & 13 & $86 \%$ \\
Male & 2 & $14 \%$ \\
\hline Amount & 15 & $100 \%$ \\
\hline
\end{tabular}




\section{COMPRABHENSWE HEAH CARE}

From Table 1 it can be seen that respondents based on the highest age are 55-60 years old as many as 8 people (53\%), and the lowest is 45-49 years old as many as 2 people (14\%). Based on data from the highest number of respondent's gender, there are 13 women (86\%) and the lowest is male gender, which is 2 people (14\%).

Table 2. Frequency distribution of pain intensity in patients with rheumatoid arthritis before and after compressing

\begin{tabular}{lcccc}
\hline \multirow{2}{*}{ Pain intensity } & \multicolumn{3}{c}{ Warm Compresses Of Ginger } \\
& \multicolumn{2}{c}{ Pretest } & \multicolumn{2}{c}{ Postest } \\
\cline { 2 - 5 } & $\mathrm{n}$ & $\%$ & $\mathrm{n}$ & $\%$ \\
\hline No pain & 0 & 0 & 0 & 0 \\
Light & 0 & 0 & 9 & 60 \\
Is & 9 & 60 & 5 & 33,3 \\
Weight & 6 & 40 & 1 & 6,7 \\
Very heavy & 0 & 0 & 0 & 0 \\
\hline Amount & 15 & 100 & 15 & 100 \\
\hline \hline
\end{tabular}

From Table 2 based on the research conducted obtained the highest pain intensity before compressing as many as 9 respondents (60\%) in the category of moderate pain and the lowest pain intensity as many as 6 respondents (40\%) in the category of severe pain, then based on research conducted after compressing, intensity the highest pain is as many as 9 respondents (60\%) in the category of mild pain and the lowest pain intensity is as much as 1 respondent (6.7\%) in the category of severe pain.

Table 3. Frequency distribution of warm ginger compresses to reduce the intensity of rheumatoid arthritis pain

\begin{tabular}{llr}
\hline \multicolumn{3}{c}{ Test Statistics $^{\mathrm{a}}$} \\
& & \\
\hline $\mathrm{Z}$ & post test - pre test & \\
\hline Asymp. Sig. (2-tailed) & & $-3.742^{\mathrm{b}}$ \\
\hline
\end{tabular}

Wilcoxon Signed Ranks Test

Based on the alternative paired Wilcoxon t-test results obtained that there is an effect of warm ginger compresses on the reduction in pain intensity in patients with rheumatoid arthritis in the work area of the Bontobahari Puskesmas with a p value $=$ $0,000<\alpha=0.05$. From this table, it was found that there was an effect of warm ginger compresses on the decrease in pain intensity in patients with rheumatoid arthritis in the work area of the Bontobahari Puskesmas.

\section{DISCUSSION}

Based on the results of this study, it can be seen that rheumatoid arthritis sufferers mostly experience pain, with pain intensity experienced before warm compresses are 


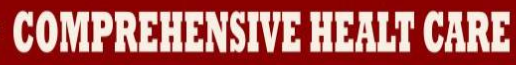

done, 9 respondents (60\%) in the moderate pain category and 6 respondents $(40 \%)$ in the severe pain category. Where is known as one of the clinical manifestations or signs and symptoms of rheumatoid arthritis is pain. International association for pain research (International Association for The Study of Pain), defines pain as a subjective sensory and unpleasant emotional experience associated with actual and potential tissue damage or that is felt in the events where damage occurs.

The results of this study are in line with the research of Bactiar.A (2012): with the title of research "The effect of ginger extract on signs and symptoms of rheumatoid arthritis in outpatients in the city health center shows that pain is a sign and symptoms that appear in patients with rheumatoid arthritis, which are found in the pre-treatment data. According to the researchers' assumption that most people with rheumatoid arthritis experience pain. Pain Caused by inflammation that attacks several joints this occurs because Rheumatoid Arthritis is a chronic systemic inflammatory disease, which causes damage to the bones. Average pain experienced before a warm ginger compress is done is experiencing moderate pain. Pain is a nursing priority that must get treatment so that no more severe damage occurs.

Based on the results of the study it can be seen the intensity of pain after a warm ginger compress from 15 respondents is known from 60\% (9 people) respondents experienced severe pain intensity experienced a decrease in moderate pain intensity after a warm ginger compress. According to Smaltzer \& Bare 2004, one of the nonpharmacological interventions that nurses can do independently in reducing the scale of pain, is by doing warm compresses on patients to reduce the intensity of rheumatoid arthritis pain. Ginger warm compresses contain cyclo-oxygenation enzymes that can reduce inflammation in rheumatoid arthritis sufferers, besides that ginger also has pharmacological effects, namely hot and spicy, where this heat can relieve pain, stiffness, and muscle spasms or the occurrence of vasodilation of blood vessels.

The results of this study are in line with research Susanti, d, (2014): with the title of the study "The effect of warm ginger compresses on the reduction in the scale of rheumatoid arthritis pain in the elderly in the social care system of tresna werdha compassion of mother of the stone cage, shows that overall there is a significant relationship between the levels of scale pain before and after giving warm compress ginger stew with a p-value of 0,000 . In the pre and post-treatment data, the pain scale 


\section{COMPRABHENSWE HEAH CARE}

from moderate to low scale was decreased and did not experience low to moderate or high pain scale.

According to the researchers' assumptions that patients who suffer from rheumatoid arthritis given a warm ginger compress, there was a decrease in pain intensity that is $60 \%$ ( 9 people) experienced mild pain intensity. This shows a decrease in pain intensity in patients suffering from rheumatoid arthritis. This decrease occurs due to the influence of warm compresses of ginger. Where can be known that ginger contains several pharmacological effects, namely spicy and hot taste that has antirheumatic properties? In this study, the majority of respondents experienced a decrease in pain intensity after a warm ginger compress was performed. However, there was one respondent who did not experience changes in intensity after compressing, this was because the respondent had suffered from rheumatoid arthritis for a very long time or was chronic.

Bivariate analysis in this study discusses the effect of warm compresses on decreasing pain intensity in rheumatoid arthritis sufferers in the work area of Bontobahari Puskesmas in 2017. From the statistical analysis of the effect of the implementation of ginger warm compresses on decreasing the intensity of rheumatoid arthritis pain, the number of respondents was 15 respondents obtained an average of average sufferers experience moderate pain before a warm ginger compress (pre-test) and there is a decrease in pain intensity after a warm ginger compress that is, on average, decreases to mild. Based on statistical results from the T-test, $p=0,000$, which means there is a significant effect between warm ginger compresses on the decrease in pain intensity in patients with rheumatoid arthritis.

The results of this study are in line with the research of Susanti, d, (2014): with the title of the study "The effect of ginger warm compresses on the reduction in the scale of rheumatoid arthritis pain in the elderly in the social care system of tresna werdha compassion of mother of caged stone, shows overall there is a significant relationship between the level of pain scale before and after giving a warm compress ginger stew with a p-value of 0,000 . In the pre and post-treatment data, the pain scale from moderate to low scale was decreased and did not experience low to moderate or high pain scale. There is a significant difference in the level of pain before and after giving warm compresses of ginger stew in the elderly with rheumatoid arthritis. According to the researchers' assumptions based on the research conducted there was a significant 


\section{COMPRABHENSWE HEAH CARE}

effect between warm compresses of ginger and a decrease in pain intensity in rheumatoid arthritis sufferers. This is in accordance with one of the nonpharmacological interventions that nurses can do independently in reducing the pain scale, namely by applying warm compresses to the patient to reduce the intensity of rheumatoid arthritis pain.

Rheumatoid arthritis is an autoimmune disease in which the joint lining becomes inflamed, causing pain, stiffness, weakness, redness, swelling, and heat, this disease occurs between the ages of 20 - 50 years. Rheumatoid arthritis is a chronic systemic inflammatory disease that attacks several joints, synovium is the part that occurs in the inflammatory process that causes damage to the joints (Khitchen, 2011). According to Potter \& Perry Skin stimulation is done to relieve pain. Warm baths compress, and stimulation of transcutaneous electrical nerves are simple steps in efforts to reduce the pain scale. warm compresses of ginger contain cyclo-oxygenation enzymes that can reduce inflammation in rheumatoid arthritis sufferers, besides that ginger also has pharmacological effects, such as hot and spicy, which can relieve pain, stiffness and muscle spasms. Based on research conducted, researchers argue that during the warm ginger compresses carried out in patients with rheumatoid arthritis, not all sufferers are able to concentrate on the ginger compresses that are given, although it has received clear explanations from researchers. Effectiveness depends on the respondent himself in receiving the sensory input given.

\section{CONCLUSIONS}

It was found from the results of this study that there was an effect of warm ginger compresses on the reduction in pain intensity in rheumatoid arthritis sufferers in the work area of the Bontobahari Puskesmas in 2017 with a p value $=0,000$. From the results of this study it is expected that respondents in the work area of the bontobahari puskesmas can apply warm compresses of ginger, to reduce the intensity of rheumatoid arthritis pain.

\section{REFERENCES}

Agung, A. A., Panggemanan, J., \& Siagian, I. (2016). Hubungan Tingkat Pengetahuan Masyarakat Dengan Tindakan Pencegahan Hipertensi Di Desa Matoboi Kecil Kecamatan Kotamagu Selatan . Jurnal kedokteran keperawatan dan tropis.

Alimul, A. H. (2014). Metode Peneltian Keperawatan Dan Tehnik Analisis Data. Jakarta: Salemba Medika. 
Brian, R. S., Rondonuwu, R., \& Onibala, F. (2015). Hunugan beban kerja dengan kejadian hipertensi pada tenaga pengajar di sma negeri 1 amurang kabupaten minahasa selatan. e journal keperawatan.

Efendi, N. (2012). Dasar-Dasar Keperawatan Kesehatan Masyarakat, Ed.2. Jakarta: EGC 1236.

Hadi, C. (2015). Efektifitas Pendidikan Kesehatan Terhadap peningkatan Pengetahuan Keluarga Tentang Hipertensi. Mutiara Medika.

Herwati, \& Sartika, W. (2013). Terkontrolnya tekanan darah penderita hipertensi berdasarkan pola diet dan kebiasaan olahraga dipadang tahun 2011. Jurnal kesehatan masyarakat.

Hesriantica, D. Z., \& Diana, R. R. (2017). Hubungan pengetahuan dan riwayat hipertensi dengan tindakan pengendalian tekanan darah pada lansia. jurnal berkala epidemiologi.

Ika, D. P., Hannan, M., \& Dea, L. C. (2017). Pengaruh Jalan Pagi Terhadap Perubahan Tekanan darah Pada Lanjut Usia Dengan Hipertensi Di Desa Kalianget Timur Kecamatan Kaliagent kabupaten sumenap. Ners Lentera.

Kholid, A. (2012). Promosi kesehatan dengan pendekatan teori perilaku, media dan aplikasinya. Jakarta: Rajawali pers.

Kumala, M. (2014). Peran Diet Dalam Pencegahan Dan Terapi Hipertensi . Damianus journal of medicine.

Kurniati, D. p., Inayah, G., \& Samaria, K. (2012). Perilaku Berolahraga dalam Upaya Pencegahan Hipertensi Wanita Usia Produktif Di Pancoran Mas Depok Jawa Barat. Arc. Com. Health.

Lasianjayani, T., \& Martini, S. (2014). Hubungan Antara Obesitas Dengan Perilaku Merokok Terhadap Kejadian Hipertensi. Jurnal Berkala Epidemiologi.

Leidi, M. M., Mulyadi, \& Onibala, F. (2017). Hubungan pengetahuan tentang die garam dengan tekanan darah pada lansiadi puskesmas bahu kota manado. e journal keperawatan.

Lisiswan, R., \& Ulia, D. D. (2016). Upaya pencegahan hipertensi.

Mardiah, A., Abdullah, A., \& Hermansyah. (2016). Pendidikan Kesehatan Dalam Peningkatan Pengetahuan,Sikap Dan Keterampilan Keluarga Dengan Hipertensi. Jurnal ilmu keperawatan.

Martono, N. (2010). Metode Penelitian Kuantitatif. Jakarta: Rajawali Pers.

Notoatmodjo, s. (2012). METODELOGI PENELITIAN KESEHATAN. Jakarta: PT RINEKA CIPTA.

Nurrahmi, U. (2015). Stop diabetes, Hipertensi, Kolestrol dan jantung koroner. Yogyakarta: Istana media.

Prihatmono, I. G., \& Puspasari, F. A. (2017). Pendidikan Kesehatan Dalam Pengelolaan Hipertensi Pada Lansia Di Posbindu BokesanNgemplak Sleman Diy. Media IImu Kesehatan.

Purwati, R., Bidjuni, H., \& Babakal, A. (2014). Pengaruh Penyuluhan Kesehatan Terhadap Pengetahuan Perilaku Klien Hipertensi Di Puskesmas Bahu Manado. E-Journal.

Rina, P. S. (2015). Faktor-Faktor Yang Berhubungan Dengan Kejadian Hipertensi Pada Penderita Rawat Inap Di Rumah Sakit Umum Sari Mutiara Medan Tahun 2014. jurnal ilmiah keperawatan.

Runtukahu, R. F., Rompas, S., \& Pondaag, L. (2015). analisis faktor faktor yang berhubungan dengan kepatuhan melaksanaakan diet pada penderita hipertensi di wilayah kerja puskesmas wolang kecamatan langgoan timur. ejournal keperrawatan. 
Saam, Z., \& Wahyuni, S. (2013). Psikologi Keperawatan. Jakarta: Rajawali Pers.

Seke, P. A., Bidjuni, H. j., \& Lolong, J. (2016). Hubungan kejadian stress dengan penyakit hipertensi pada lansia di balai penyantunan lanjut usia senjah cerah kacamatan mapanget kota manado. E journal keperawatan.

sudarsono, E. k., Aji sasmita, J. F., Handyasto, A. B., Arissaputra, S. s., \& Kuswantiningsih, N. (2017). Peningkatan pengetahun tentang hipertensi guna perbaikan tekanan darah pada anak muda di dusun japan,margodadi,sayegan,sleman,Yogyakarta. Jurnal pengabdian pada masyarakat .

Sugiyono. (2012). Metode Penelitian Kuantitatif Kualitatif dan R\&D. Bandung: Alfabeta.

Sujarweni, W. (2014). Metode Penelitian Keperawatan. Yogyakarta: Gava Media.

Sulistyarini, I. (2013). Terapi Relaksasi Untuk Menurunkan Tekananan Darah Dan Meningkatkan Kualitas Hidup Penderita Hipertensi . Jurnal Psikologi.

sumah, D. F. (2015). Efektifitas pendidikan kesehatan terhap kesehatan terhadap penurunan tekanan darah pasien hipertensi di puskesmas kacamatan amahusu ambon. pendidikan kesehatan,tekanan darah sostolik dan diastolik.

Sumantri, H. A. (2011). Metodologi Peneitian Kesehatan. Jakarta: Kencana.

Sutanto. (2010). CEKAL (cegah dan tangkal) Penyakit MODEREN. Yogyakarta: C.V ANDI OFFEST.

Sutanto, Y., \& Alfian, R. (2015). Perbaikan Perilau Dan Tekanana Darah Pasien Hipertensi Di RSUD H.MOCH ANSARI SALAH Banjarmasin serelah Pemberian Leafleat Edukasi Hipertensi Dan Terapinya. Jurbal Ilmiah Menuntung.

Tribowo, C., \& Elisya, M. P. (2015). Pengatr dasar ilmu keperawatan. Yogyakarta: Nuna medika.

Udjianti, W. J. (2013). Keperawatan Kardiovaskular. Jakarta: Salemba Medika.

Utami, N., \& Wulan, A. S. (2017). Komsumsi pisang ambong sebagai terapi non farmakologi hipertensi. jurnal keperawatan.

Widianingrum, R., \& Dewi, H. (2013). Efektifitas penyuluhan tentang hipertensi pada masyarakat rentang usia 45-60 tahun dibandingkan dengan masyarakat rentang usia 61-75 tahun. Jurnal kedokteran muhammdiyah.

Yulanda, G., \& Lisiwanti, R. (2017). Penata Laksanaan Hipertensi Primer. Majoriti.

Yumono, G. A., Ridwan, M., \& Hanafi, M. (2017). Pengaruh Pendidikan Kesehatan Tentang Hipertensi Terhadap Tingkat Kecemasan Pada Penderita Hipertensi Di Kabupaten Magelang . Jurnal Keperawatan Soedirman.

Zahidah, A. K., Udiyono, A., \& Adi, M. S. (2016). Gambaran Faktor-Faktor Tekanan Darah Pada Asekptor KB Hormonal Di Wilayah Kerja Puskesmas Kedungmundu 2016. E-juurnal Kesehatan Masyarakat. 